\title{
About the editors
}

\section{Adam Lindgreen}

After studies in chemistry (Copenhagen University), engineering (the Engineering Academy of Denmark), and physics (Copenhagen University), Professor Adam Lindgreen completed an MSc in food science and technology at the Technical University of Denmark. He also finished an MBA at the University of Leicester. He received his Ph.D. in marketing from Cranfield University. His first appointments were with the Catholique University of Louvain (2000-2001) and Eindhoven University of Technology (2002-2007). Subsequently, he served as Professor of Marketing at Hull University's Business School (2007-2010); University of Birmingham's Business School (2010), where he also was the research director in the Department of Marketing; and University of Cardiff's Business School (2011-2016). Under his leadership, the Department of Marketing and Strategy at Cardiff Business School ranked first among all marketing departments in Australia, Canada, New Zealand, the United Kingdom, and the United States, based upon the hg indices of senior faculty. Since 2016, Adam Lindgreen has been Professor of Marketing at Copenhagen Business School, where he also heads the Department of Marketing. Since 2018, he also is Extraordinary Professor with University of Pretoria's Gordon Institute of Business Science.

Adam Lindgreen has been a visiting professor with various institutions including Georgia State University, HEC Paris, and Melbourne University. His publications have appeared in Business Horizons, California Management Review, Entrepreneurship and Regional Development, Industrial Marketing Management, International Journal of Management Reviews, Journal of Advertising, Journal of Business Ethics, European Journal of Marketing, Journal of Business and Industrial Marketing, Journal of Marketing Management, Journal of the Academy of Marketing Science, Journal of Product Innovation Management, Journal of World Business, Organization Studies, Psychology \& Marketing, and Supply Chain Management: An International Journal, among others.

Adam Lindgreen's 23 books in business and economics include $A$ Stakeholder Approach to Corporate Social Responsibility (with Kotler, Vanhamme, and Maon), Managing Market Relationships, Memorable Customer Experiences (with Vanhamme and Beverland), Not All Claps and Cheers (with Maon, 
Vanhamme, Angell, and Memery), Public Value (with Koenig-Lewis, Kitchener, Brewer, Moore, and Meynhardt), and Sustainable Value Chain Management (with Maon, Vanhamme, and Sen).

The recipient of the "Outstanding Article 2005" award from Industrial Marketing Management and the runner-up for the same award in 2016, he serves on the board of several scientific journals; he is Co-Editor-in-Chief of Industrial Marketing Management and previously was the joint editor of the Journal of Business Ethics' section on corporate responsibility. His research interests include business and industrial marketing management, corporate social responsibility, and sustainability. He has been awarded the Dean's Award for Excellence in Executive Teaching. Furthermore, he has served as an examiner (for dissertations, modules, and programs) at a wide variety of institutions around the world.

Adam Lindgreen is a member of the International Scientific Advisory Panel of the New Zealand Food Safety Science and Research Centre (a partnership between government, industry organizations, and research institutions), as well as of the Chartered Association of Business Schools' Academic Journal Guide (AJG) Scientific Committee in the field of marketing.

Beyond these academic contributions to marketing, Adam Lindgreen has discovered and excavated settlements from the Stone Age in Denmark, including the only major kitchen midden-Sparregård - in the south-east of Denmark; because of its importance, the kitchen midden was later excavated by the National Museum and then protected as a historical monument for future generations. He is also an avid genealogist, having traced his family back to 1390 and published widely including eight books and numerous articles in scientific journals (Personalhistorisk Tidsskrift, The Genealogist, and Sloegt \& Data) related to methodological issues in genealogy, accounts of population development, and particular family lineages.

\section{Anthony Di Benedetto}

Dr. C. Anthony Di Benedetto is Professor of Marketing and Supply Chain Management and Senior Washburn Research Fellow at the Fox School of Business, Temple University. He has held visiting professorships at Bocconi University, Politecnico di Milano, Technische Universiteit Eindhoven, Kansai University, Yonsei University, WHU, St. Petersburg State University, Edhec Business School, and IESEG School of Management. In 2010, Anthony Di Benedetto was named the Fulbright-Kathryn and Craig Hall Chair in Entrepreneurship and spent a semester at the Wirtschaftsuniversität Wien.

Anthony Di Benedetto holds a Ph.D. in Administration, an MBA in Marketing, and a BSc in Chemistry, all from McGill University. He taught 
at the Université du Québec à Montréal (in French) and the University of Kentucky prior to joining Temple. Since arriving at Temple he has taught in Temple's Professional MBA, Executive MBA, International Executive MBA (Singapore, Cali, and Bogotà), Online MBA, and International MBA programs, as well as at the Ph.D., DBA, BBA, and OBBA programs. In 2017, Anthony Di Benedetto taught in the Fox School's Global Immersion program in Vienna; years earlier, in 1992, he was one of the first instructors to teach business classes at Temple's Rome campus. He is a recipient of Temple University's Great Teacher Award, the highest teaching honor bestowed by Temple University. He has also received the Lindback Award for teaching excellence, a Department of Marketing teaching award, and the Lynne A. Cronfeld Research Award/Grant. In 2017, he was selected as Faculty of the Year by students in both the DBA and OMBA programs. In 2015, he received the Musser Excellence in Leadership Award in Research, the highest honor bestowed by the Fox School of Business.

Anthony Di Benedetto is Co-Editor-in-Chief of Industrial Marketing Management, and Editor-in-Chief of Journal of International Consumer Marketing. He served as Editor of Journal of Product Innovation Management for nine years. He is co-author with Merle Crawford of New Products Management, the leading textbook in new product development.

Anthony Di Benedetto has been named one of the 50 leading research scholars worldwide in innovation and technology management by the International Association of Management of Technology. He has over 115 refereed academic articles published, in journals including IEEE Transactions on Engineering Management, Industrial Marketing Management, Journal of International Business Studies, Journal of Operations Management, Journal of Product Innovation Management, Journal of the Academy of Marketing Science, Management Science, Strategic Management Journal, Columbia Journal of World Business, and elsewhere. A paper published in IEEE Transactions on Engineering Management was named the Best Paper in that journal for 2008. He has been named multiple times to the Dean's Research Honor Roll of the School of Business and Management.

He is a certified New Product Development Professional (NPDP) and is listed in Marquis Who's Who in the World, Marquis Who's Who in America, and Marquis Who's Who in American Education.

\section{Joëlle Vanhamme}

Dr. Joëlle Vanhamme is Professor of Marketing at the Edhec Business School. She received her Ph.D. from the Catholic University of Louvain (Louvain School of Management). Joëlle Vanhamme has been Assistant Professor at 
Rotterdam School of Management, Associate Professor at IESEG School of Management, and a visiting scholar with Delft University of Technology, Eindhoven University of Technology, Hull University's Business School, Lincoln University, and the University of Auckland's Business School. Her research has appeared in Business Horizons, California Management Review, Industrial Marketing Management, International Journal of Research in Marketing, Journal of Advertising, Journal of Advertising Research, Journal of Business Ethics, Journal of Consumer Satisfaction, Dissatisfaction and Complaining Behavior, Journal of Customer Behaviour, Journal of Economic Psychology, Journal of Marketing Management, Journal of Retailing, Marketing Letters, Organization Studies, Psychology \& Marketing, Recherche et Applications en Marketing, and Supply Chain Management: An International Journal, among others.

\section{John Nicholson}

Dr. John Nicholson has a background in the agricultural supply industry, and his first qualification was in agricultural merchanting. He completed his first degree in business studies at the University of Hull in 2000, an MSc in international marketing at the University of Leeds in 2001, and a Ph.D. in Management from the University of Hull in 2009. He is a Senior Fellow of the Higher Education Academy, a Fellow of the Chartered Management Institute, and a Member of the Chartered Institute of Marketing. His academic career began in 2002 as a lecturer in marketing and business strategy at the University of Hull until he left to take up the post of reader in strategy at Sheffield Hallam University in 2015. He joined Huddersfield University as a Chair in Strategic Management in 2017. Over a period of ten years, he has completed twelve doctoral supervisions in diverse areas from change management, SME development and sales management to reverse logistics in waste supply chains. John Nicholson has a variety of research interests, which have included knowledge transfer, supply chains, public-private sector interaction, relational space, entrepreneurship, co-opetition, and regional interaction. He has published in journals such as Industrial Marketing Management, International Business Review, Journal of Business Research, Journal of Management Inquiry, Marketing Theory, Policy and Politics, and Supply Chain Management. Underpinning his work is a philosophical interest in the agency-structure interaction, and he has published several articles drawing on systems thinking, critical realist, and structurationist ideas. He has also published articles examining the craft of academic writing and doctoral supervision. John Nicholson has served as Associate Editor of Industrial Marketing Management since 2017 and is a reviewer for a number of journals. 